2 Long CL, Jeevanandam M, Kim BM, Kinney JM. Whole body protein synthesis and catabolism in septic man. Am $\mathcal{f}$ Clin Nutr 1977;30:1340-4.

${ }^{3}$ Crane CW, Picou D, Smith R, Waterlow JC. Protein turnover in patients before and after elective orthopaedic surgery. Brf Surg 1977;64:129-33.

4 O'Keefe SJD, Sender PM, James WPT. Catabolic loss of body nitrogen in response to surgery. Lancet 1974 ;ii:1035-7.

${ }^{5}$ Bistran BR, Winterer JC, Blackburn GL, Scrimshaw NS. Failure of yellow fever immunization to produce a catabolic response in individuals fully adapted to a protein-sparing modified fast. Am $\mathcal{f}$ Clin Nutr 1977; 30:1518-22.

${ }^{6}$ Kielmann AA. Weight fluctuations after immunization in a rural preschool child community. Am $\mathcal{F}$ Clin Nutr 1977;30:592-8.

${ }^{7}$ Paul AA, Southgate DAT. McCance and Widdowson's the composition of foods. 4th ed. London: HMSO, 1978.

8 Fawcett JK, Scott JE. A rapid and precise method for the determination of urea. $\mathcal{F}$ Clin Pathol 1960;13:156-9.

9 Golden MHN, Waterlow JC. Total protein synthesis in elderly people: a comparison of results with $\left({ }^{15} \mathrm{~N}\right)$ glycine and $\left({ }^{14} \mathrm{C}\right)$ leucine. Clin Sci Mol Med $1977 ; 53: 277-88$.

10 Waterlow JC, Garlick PJ, Millward DJ. Protein turnover in mammalian tissues and in the whole body. Amsterdam: North-Holland, 1978:225-99.

11 Waterlow JC, Golden MHN, Garlick PJ. Protein turnover in man measured with ${ }^{15} \mathrm{~N}$ : comparison of end products and dose regimes. Am $\mathcal{F}$ Physiol $1978 ; 235$ :E165-74.
12 Garlick PJ, Clugston GA, Waterlow JC. Influence of low-energy diets on whole-body protein turnover in obese subjects. Am 7 Physiol $1980 ; 238$ : E235-44.

13 Snedecor GW, Cochran WG. Statistical methods. 6th ed. Ames, Iowa: Iowa State University Press, 1967:329.

14 Garlick PJ, Clugston GA, Swick RW, Waterlow JC. Diurnal pattern of protein and energy metabolism in man. Am $\mathfrak{f}$ Clin Nutr (in press).

15 Beisel WR, Goldman RF, Joy RJT. Metabolic balance studies during induced hyperthermia in man. $\mathcal{F} A p p l$ Physiol 1968;24:1-10.

16 Lust G. Effect of infection on protein and nucleic acid synthesis in mammalian organs and tissues. Fed Proc 1966;25:1688-94

17 Young VR, Chen SI, Newberne PM. Effect of infection on skeletal muscle ribosomes in rats fed adequate or low protein. $\mathcal{F}$ Nutr 1968;94:361-8.

${ }^{18}$ Ryan NT. Metabolic adaptations for energy production during trauma and sepsis. Surg Clin North Am 1976;13:1073-90.

19 Long CL, Schiller WR, Blakemore WS, Geiger JW, O'Dell M, Henderson $\mathrm{K}$. Muscle protein catabolism in the septic patient as measured by 3methylhistidine excretion. Am $\mathcal{F}$ Clin Nutr 1977;30:1349-52.

${ }^{20}$ Stein TP, Leskiw MJ, Wallace HW, Oram-Smith JC. Changes in protein synthesis after trauma: importance of nutrition. Am $\mathcal{F}$ Physiol 1977 ;233 : E348-55.

(Accepted 29 May 1980)

\title{
School screening for scoliosis: cohort study of clinical course
}

\author{
ROBERT A DICKSON, PETER STAMPER, ANNE-MARIE SHARP, PAUL HARKER
}

\section{Summary and conclusions}

A visual examination of 1764 Oxford schoolchildren for scoliosis was followed by low-dose radiography of the spine in those who showed evidence of asymmetric body topography; radiography was repeated a year later to assess progression. Forty-four children had curves of $10^{\circ}$ or more. Two had a congenital abnormality and the remaining 42 were classified according to the type of curve: sacral tilt (compensatory), spinal (idiopathic), or combined (sacral tilt and spinal). Progression occurred in $6(14 \%)$ children, none of whom had only a sacral tilt.

These results suggest that only by measuring sacral tilt can benign compensatory curves be differentiated from true idiopathic scoliosis.

\section{Introduction}

Without careful scrutiny of the community most children with progressive scoliosis remain undetected, only to present in later life with permanent disability. ${ }^{1}$ Progression can, however, be prevented by early detection and effective conservative treatment while the deformities are mild and flexible. ${ }^{2}$ Only $10 \%$ of curves detected by screening are progressive, most being nonprogressive lumbar curves. The characteristics of deformities that progress and those that are benign are not clear, but compensatory non-progressive scolioses are commonly produced by a tilt of the sacrum secondary to inequality in the length of the legs. ${ }^{3}$ This cohort study of the clinical course of scoliosis is based on the observation that in many cases of benign scoliosis

Nuffield Department of Orthopaedic Surgery, Nuffield Orthopaedic Centre, Oxford OX3 7LD

ROBERT A DICKSON, CHM, FRCS, clinical reader in orthopaedic surgery PETER STAMPER, FRCR, consultant radiologist

ANNE-MARIE SHARP, MCSP, senior aftercare physiotherapist

PAUL HARKER, MFCM, community physician detected by school screening the curve is compensatory to a tilt of the sacrum but that this tilt is a result of an inherent developmental problem of the pelvis itself rather than any inequality in the length of the legs.

\section{Patients and methods}

A senior physiotherapist experienced in spinal disorders screened 176413 and 14 year olds in five Oxford schools for the presence of a spinal deformity by visual inspection with the patient standing erect and leaning forward (the "one-minute school screening test").4 Those showing evidence of asymmetric body topography were examined with low-dose spinal radiography ${ }^{5}$ in the erect position. The radiographs were measured by Cobb's method, ${ }^{6} 7$ and those children with scolioses of $10^{\circ}$ or more were examined clinically to exclude a musculoskeletal disease as a cause of the deformity. One year later these children were re-examined and radiographs taken using the low-dose technique in the presence of two of us (RAD and PS) to eliminate postural variation.

Examination of the initial standing radiograph showed that many children seemed to have a sacral tilt with reference to the horizontal fluid level in the stomach included in the same radiograph (fig 1). The low-dose spinal radiograph taken at follow-up therefore included a contrast-medium spirit-level ${ }^{8}$ placed on the $x$-ray cassette just below the femoral heads. The site and magnitude of any scoliosis and the sacral tilt were recorded from these films. These data were compared with those of the initial low-dose radiograph to detect progression of the curve (a curve reaching $20^{\circ}$ or more). Significances of differences in the mean size of the curves were confirmed statistically using Student's $t$ test. The relation between magnitude of sacral tilt and magnitude of scoliosis was confirmed by deriving the correlation coefficient, r. Observations concerning proportions of type of scoliosis in different sites in the spine and observations concerning progression were confirmed using the $\chi^{2}$ test.

\section{Results}

Of the 1764 children screened $147(8.3 \%)$ showed evidence of asymmetry of body topography and 121 of these $(6.9 \%)$ had radiographic evidence of a scoliosis. Seventy-seven children (4.3\%) had curves of less than $10^{\circ}$ but $44(2.5 \%)$ had scolioses measuring $10^{\circ}$ or 


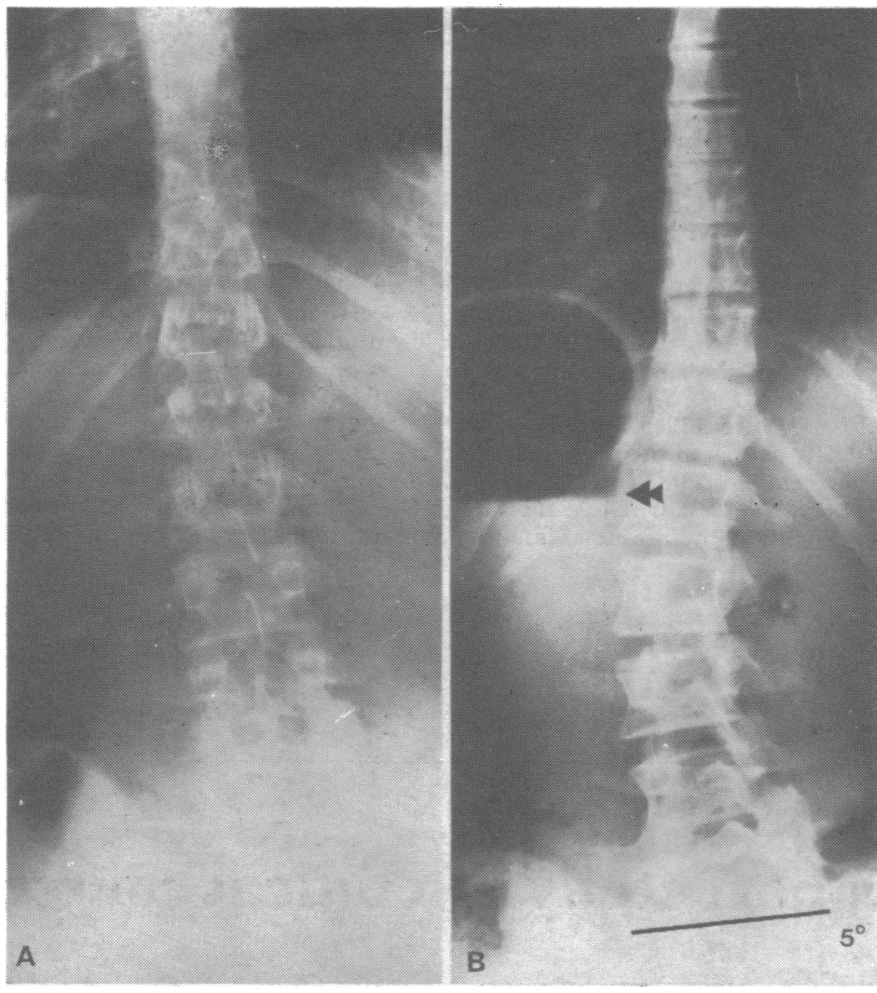

FIG 1 -(a) Posteroanterior radiograph of thoracolumbar spine; $x$-ray cassette was inappropriately placed in holder, and there was no discernible horizontal reference level to compare with upper border of sacrum. (b) Posteroanterior radiograph of thoracolumbar spine; horizontal gastric fluid level was sharply demarcated (arrowed), and upper border of the sacrum was tilted $5^{\circ}$; there was a compensatory lumbar scoliosis above.

TABLE I-Numbers(percentages) of children with scoliosis

\begin{tabular}{llr}
\hline \multicolumn{2}{c}{ Type of scoliosis } & No (\%) \\
\hline Non-genital & Sacral tilt only & \\
Sacral & Sacral tilt and hip tilt & $9(21)$ \\
Spinal & Idiopathic only & $6(14)$ \\
Combined & Idiopathic and sacral tilt & $18(41)$ \\
& Idiopathic, sacral tilt, and hip tilt & $4(9)$ \\
& $2(5)$ \\
Congenital & Idiopathic and hip tilt & $3(7)$ \\
Total & & $2(5)$ \\
& & $44(100)$
\end{tabular}

more. The mean age of these 44 children ( 32 girls, 12 boys) was 14 years, 2 months (range 13 years, 4 months to 15 years, 2 months). One child had a double structural curve, and therefore the 44 children had 45 curves among them.

\section{SITE AND AETIOLOGY OF THE SCOLIOSES}

Eight curves were thoracic, 11 were thoracolumbar, and 26 were lumbar. In two children the scoliosis was a result of congenital bony abnormality of the spine (unilateral failure of segmentation) but in the remaining 42 children no vertebral abnormality could be detected radiographically. Twenty-six children $(62 \%$ of the non-congenital cases) had a tilt of the sacrum in the direction of the convexity of the curve. In the remaining 18 cases the upper border of the sacrum was horizontal and the scoliosis was inherent to the spine itself. Three types of scoliosis could therefore be distinguished: sacral tilt, spinal, and combined (sacral tilt and spinal) (table I). In nine of the children with a sacral tilt there was no discrepancy in the length of the legs and the obliquity of the upper border of the sacrum was entirely due to pelvic asymmetry (fig 2). In six the obliquity of the sacrum was a result of a combination of pelvic asymmetry and a leg-length discrepancy. The sacral tilt in the children in the combined group was either because of pelvic asymmetry, leg-length discrepancy, or a combination of the two.
TYPE OF SCOLIOSIS AND SITE, CURVE MAGNITUDE, AND SACRAL-TILT MAGNITUDE

All scolioses in children in the sacral-tilt group were situated in the lumbar region and the lower end-vertebra of the curve was the sacrum itself. In those in the spinal group only two curves were in the lumbar region, the remainder being either thoracic (seven children) or thoracolumbar (nine).

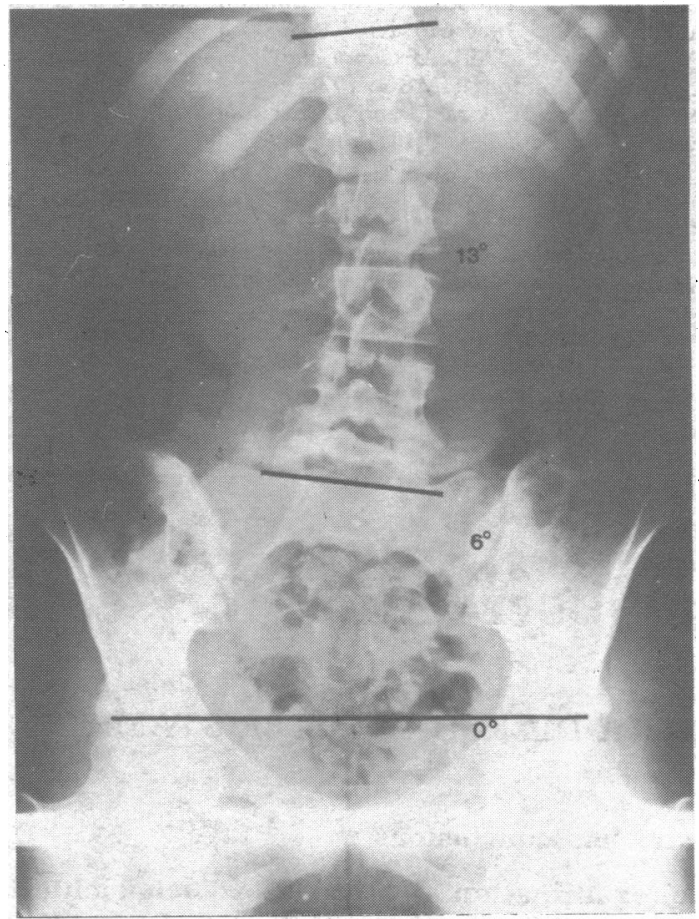

FIG 2-Posteroanterior radiograph of lumbar spine, pelvis, and hips incorporating contrast-medium spirit level just below femoral heads. There was no leg-length discrepancy but sacrum was tilted $6^{\circ}$ and there was compensatory lumbar scoliosis above.

\section{CURVE PROGRESSION}

Progression of the curve was noted in $14 \%$ of the children with non-congenital scolioses. Progression did not, however, occur in those in the sacral-tilt group and deterioration was noted only in children in the spinal and combined groups (table II). Progression was noted in $38 \%$ of all thoracic curves, $18 \%$ of thoracolumbar curves (fig 3), and only $4 \%$ of lumbar curves; these differences in proportions were significant $(p<0.05)$.

TABLE II-Curve magnitude (as means $\pm S D$ ) in relation to sacral tilt (given as means $\pm S D$ ) and progression in three groups of children with different types of scoliosis

\begin{tabular}{|c|c|c|c|c|c|}
\hline $\begin{array}{l}\text { Type of } \\
\text { scoliosis }\end{array}$ & $\begin{array}{l}\text { Curve magnitude } \\
\text { (degrees) }\end{array}$ & $\begin{array}{l}\text { Sacral tilt } \\
\text { (degrees) }\end{array}$ & $\begin{array}{c}\text { Curve: } \\
\text { tilt } \\
\text { ratio }\end{array}$ & $\begin{array}{l}\text { Curve: tilt } \\
\text { correlation }\end{array}$ & $\begin{array}{l}\text { No (\%) with } \\
\text { progression }\end{array}$ \\
\hline $\begin{array}{l}\text { Sacral } \\
\text { Spinal } \\
\text { Combined }\end{array}$ & $\begin{array}{l}11 \cdot 9 \pm 1 \cdot 9 \\
14 \cdot 2 \pm 4 \cdot 7 \\
14.9 \pm 2 \cdot 4\end{array}$ & $\begin{array}{l}5.9 \pm 0.9 \\
0 \\
3 \cdot 7 \pm 1.3\end{array}$ & $\begin{array}{l}2: 1 \\
4: 1\end{array}$ & $\begin{array}{l}r=0.8 ; p<0.001 \\
r=0.45 ; \mathrm{NS}\end{array}$ & $\begin{array}{l}4(22) \\
2(20)\end{array}$ \\
\hline
\end{tabular}

NS $=$ Not significant

\section{Discussion}

The prevalence of scoliosis in Oxford schoolchildren was similar to that noted in other series. ${ }^{4-14}$ The one-minute school screening test proved an effective method of examining for a scoliosis with only $18 \%$ of false-positives when submitted to radiographic confirmation. The radiographic screening of schoolchildren, however, raises important ethical questions, 
particularly in relation to the dosage to the breasts and gonads. By taking the spinal radiograph in the posteroanterior direction and incorporating an air gap the breast dose to the adolescent girl is reduced by a factor of 50, a dose which is similar to the annual background dose received in many parts of Britain. ${ }^{5}$ This is particularly important when radiographically monitoring those with progressive curves.

Previous screening programmes have produced high prevalence rates of scoliosis. Most cases are usually classed as idiopathic, even though very few actually progress. This study explains this finding by showing that a substantial proportion of scolioses are entirely, or partially, a result of a tilt of the sacrum in the direction of the convexity of the curve. Scoliosis did not progress in any of the children with curves caused solely by a sacral tilt. The compensatory lumbar scoliosis commonly produced by a tilt of the sacrum secondary to inequality in the legs is never progressive. ${ }^{3}$ Children with this

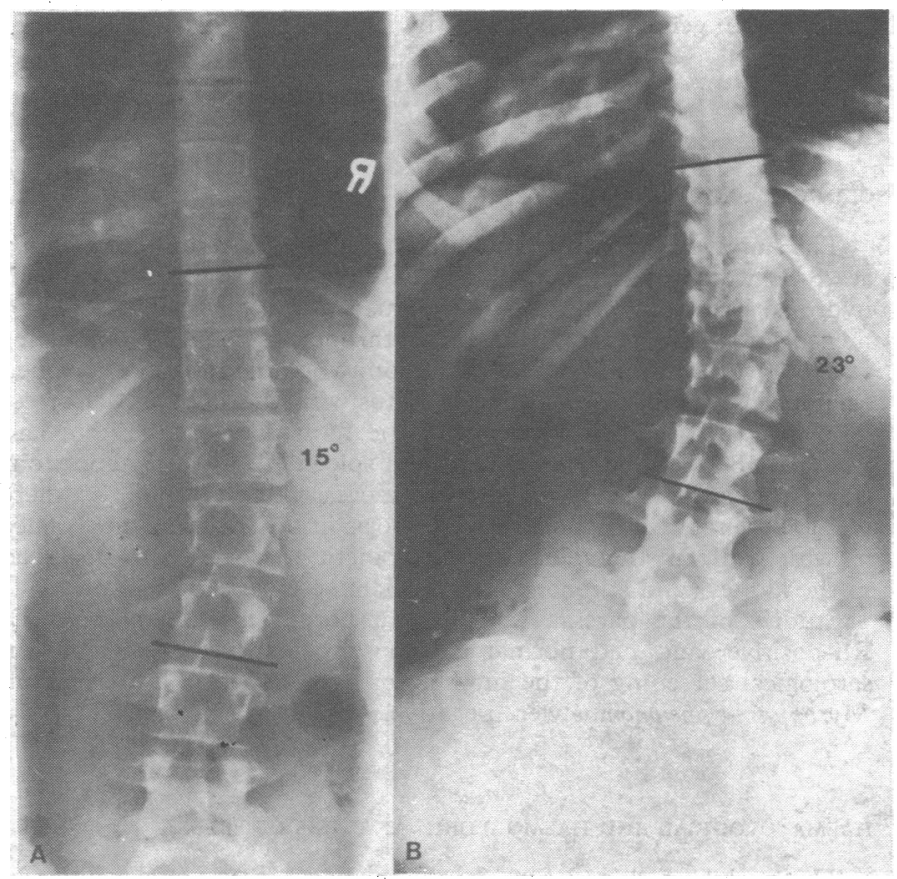

FIG 3-(a) Rosteroanterior radiograph of thoracolumbar spine. There was a $15^{\circ}$ thoracolumbar scoliosis and no sacral tilt. (b) Posteroanterior radiograph of spine of same patient one year later. Curve had progressed to $23^{\circ}$. problem present because of their unequal leg lengths, and their compensatory scoliosis is noted as an associated feature on clinical examination. Patients in this study whose scoliosis was a result of a sacral tilt would not have presented clinically because the tilt of the sacrum is a function of asymmetry of the pelvis rather than unequal leg lengths.

Before the introduction of school screening programmes analysis of patients presenting for treatment of a scoliosis showed a large preponderance of girls over boys, almost consistent progression, and relatively large numbers of thoracic curves. $^{3}$ With the advent of screening, many small nonprogressive lumbar curves of little importance have been detected with a female:male sex ratio approaching $1: 1$. Further cohort studies should include a horizontal radiographic level so that minor, non-progressive curves, as a consequence of a pelvic tilt, can be identified.

\section{References}

1 Bjure J, Nachemson A. Non-treated scoliosis. Clin Orthop 1973;93:44-52. 2 Kane WJ. An analysis of scoliosis prevalence studies. In: Zorab PA, ed. Scoliosis: proceedings of a fifth symposium. London: Academic Press, 1977:415-531.

3. James JIP. Scoliosis. Edinburgh: Churchill-Livingstone, 1976:7.

- Brooks HL. Idiopathic scoliosis-results of a prospective study. In: Zorab PA, ed. Scoliosis: proceedings of a fifth symposium. London: Academic Press, 1977:11-30.

5 Ardran GM, Coates R, Dickson RA, Dixon-Brown A, Harding FM. Assessment of scoliosis in children. Low-dose radiographic technique. $\mathrm{Br} \mathcal{\mathcal { F }}$ Radiol (in press).

- Cobb JR. Outline for the study of scoliosis. In: Edwards JW, ed. Instructional course lecture. Ann Arbor, Michigan: the American Academy of Orthopaedic Surgeons, 1948;5:261.

7 Whittle MW, Evans M. Instrument for measuring the Cobb angle in scoliosis. Lancet' $1979 ;$ i :414.

Ottander HG. Simple $x$-ray method for measuring leg length discrepancy. Technical note. Ilford $x$-ray focus $1977 ; 15: 3$.

- Armstrong GWD, Adair IV, Van Wijk MR. The evaluation of Moire topography as a method for scoliosis screening programme. $\mathcal{f}$ Bone Foint Surg 1977;59B:505.

10 Longstein J. Screening for spinal deformities in Minnesota schools. Clin Orthop 1977;126:33-42.

11 Rogala EJ, Drummonds DS. Idiopathic scoliosis a progressive study of the incidence and natural history based on a school screening of 26447 children. $\mathcal{F}$ Bone foint Surg 1977;59B:505.

12 Shands AR, Eisenberg HB. The incidence of scoliosis in the state of Delaware. A study of 50000 . microfilms of the chest made during a survey for tuberculosis. F Bone f Surg 1955;37A:1243-9.

13 Span Y, Robin G, Makin K. The incidence of scoliosis in school children in Jerusalem. F Bone foint Surg 1976;58B:379.

14 Rogala EJ, Drummond DS, Gutt J. Scoliosis incidence and natural history. f Bone foint Surg 1978;60A:173-6.

(Accepted 17 fune 1980)
ONE HUNDRED YEARS AGO A correspondent of the Boston Medical and Surgical fournal for March 25th, reports that the members of the. Academy of Natural Sciences and the physicians of Philadelphia have lately been favoured with an opportunity of recording some very interesting facts in regard to elephant breeding and the social habits of the relic of a former age. Professor Leidy, of the University of Pennsylvania, and Dr Chapman, of the Jefferson College, have especially interested themselves in the case, and have made several examinations of the elephant cow during gestation. The female elephant Hebe, on May 25th, 1878, was twice covered by a male elephant, a performing member of the same troup of animals. In the act of copulation, no peculiarity was observed that would distinguish elephants from other animals. At an examination in March 1879, by Drs Leidy, Penrose, Allen, Chapman, John $\mathbf{H}$ Brinton, and others, the two large mammary glands, situated upon the thorax, immediately between the front legs, .were observed to be swollen; the nipples were prominent, and the superficial veins were quite marked. Large sebaceous glands were noticed in the roof of the mouth and behind the eyes. The little elephant was born on March 10th, 1880, making the entire period of gestation six hundred and fifty-five days, which is beyond the term usually assigned of twenty months. The placenta, which was zonular, was presented to the Academy of Natural Sciences; a dried preparation of it will probably be made by Dr Chapman. The mother is about eighteen to twenty years of age, and weighs eight thousand pounds. The birth occurred about $2.30 \mathrm{AM}$. The night watchman gave the following account. When the calf was born, six other elephants, chained upon the same platform, threw up their trunks, and, dancing around as far as their chains would let them, set up a trumpeting that produced a scene of wild excitement. The mother picked up the calf with her trunk and threw it across the stable, a distance of about twenty yards; then, breaking her chains, she started after the little one, tearing down the railing and demolishing a stove-pipe in her course. The keeper now came in, and under his direction the animal became quiet and was again secured, and has remained docile. The new arrival is a female, weighing at birth two hundred and thirteen and one-half pounds; thirty-five inches in height; four feet six inches long; and around the body (girth), three feet eleven inches. After the mother threw her, the baby elephant picked herself up and went around the room; and when the excitement was subdued, she was led back to her mother, who received her with many caresses. (British Medical fournal, 1880.) 